\title{
The professional learning needs and priorities of higher- education-based teacher educators in England, Ireland and Scotland
}

\author{
Gerry Czerniawski ${ }^{*}$, Donald Grayb, Ann MacPhailc, Yvonne Bain ${ }^{\mathrm{d}}$, Paul Conwaye and Ainat \\ Guberman ${ }^{\mathrm{f}}$ \\ ${ }^{a}$ The Cass School of Education and Communities, University of East London, England; ${ }^{b}$ The School of \\ Education, University of Aberdeen, Scotland; cUniversity of Limerick, Ireland; dUniversity of \\ Aberdeen, Scotland; eUniversity of Limerick, Ireland; fThe Mofet Institute, Tel-Aviv, Israel
}

\begin{abstract}
Against a rapidly changing policy landscape for teacher education, exacerbated by 'Brexit' in the UK, findings are presented from an electronic survey of 272 higher-education based teacher educators in England, the Republic of Ireland and Scotland about their experiences of, and priorities for, professional learning. While the data generated were mainly quantitative data, qualitative features were embedded within the survey design. Both types of data have been used to draw out complexities that emerge when exploring a professional group of educators responsible for the preparation of a future generation of teachers. The findings are presented and discussed in relation to the professional demographics of the sample, research expectations placed on them and teacher educators' priorities for professional learning. Given the unique occupational position of teacher educators, their importance in the quality of teacher education and the lack of formal focus on their professional development, our starting point for teacher educators' professional development lies in their practice situated and positioned within global, regional, national and local policy contexts.
\end{abstract}

Key words: teacher education; teacher educators; teacher training; professional development; professional learning; Ireland; Scotland; England.

\section{Introduction}

Globally education is in a state of constant flux, with international comparisons requiring policymakers to re-examine their education systems and how to improve children's performance in schools (Gray 2010; European Commission 2015). The focus of such attention is often on the professional development and education of teachers. However, as pointed out by Goodwin et al. (2014), 'common sense reasoning says that quality teacher education relies on quality teacher educators. Yet, minimal attention has been paid to what teacher educators should know and be able to do' (p. 1). Zeichner (1999) concluded that, in the USA, little was known about how teacher educators worked, or should work, until the last decade of the 20th century. The situation was similar in Europe, and Lunenberg and Willemse (2006) point out that teacher educators in almost all European Union countries enter the field without any formal preparation, and often with little or no support from more experienced colleagues. At present, few systemic routes for teacher educators' ongoing learning, and little research documentation of these routes, exist (Murray, Czerniawski and Barber 2011; Berry 2013). This article presents findings from a strand of a larger international study on professional learning undertaken by the International Forum for Teacher Educator Development (InFo-TED), of 1,158 higher-education based teacher educators in Belgium, England, Israel, the Netherlands, Norway, the Republic of Ireland and Scotland (Czerniawski, MacPhail and Guberman 2017). In that study the comparative needs analysis of university-based teacher educators revealed in all countries only moderate satisfaction with participants' experiences of professional learning. Other than Gibraltar all Anglophone countries 
in Europe, where English is the official language, can be found within the United Kingdom and the Republic of Ireland. For partly pragmatic purposes, this study concentrates on three Anglophone countries currently represented on the InFo-TED Council, namely the Republic of Ireland, Scotland and England. However all three countries have recently encountered, with varying degrees, the rationalization, restructuring and reconfiguration of their teacher education systems. Exploring the variety and depth of higher-education-based teacher educators' experiences of professional learning, this article focuses on the extent to which, in these three countries, these experiences have addressed university-based teacher educators' professional learning needs. While recognising their contestability and interchangeability within the literature, 'professional development' and 'professional learning' are used as portmanteau terms to describe the formal and informal processes that enable teacher educators to improve their professional practice throughout their careers, with a commitment to transform education for the better. 'Teacher educator' is used here as the inclusive term to encompass all who are professionally engaged in the initial and ongoing education of teachers including those who work in universities, colleges and schools. However the focus of this article is on those teacher educators employed in universities. The article introduces the reader to competing definitions associated with teacher educators' professional development, followed by a brief contextualisation of teacher education in England, Ireland and Scotland. The findings are then presented and discussed in relation to the professional demographics of the sample, the professional learning activities valued by teacher educators and those influential factors that determine teacher educators' engagement in those activities.

\section{Teacher educators' professional learning}

Teacher educators' professional learning is under-researched, with much of the literature drawing on teachers' continuing professional development (CPD) in schools. Kennedy (2005), for example, has identified nine models of teachers' CPD in international literature, classified in relation to their capacity for supporting professional autonomy and transformative practice. These teacher-based models (training; award-bearing; deficit; cascade; standards-based; coaching and mentoring; community of practice; action research; transformative) have been usefully applied to literature on teacher educators' professional learning (see Bates, Swennen and Jones 2011; Beauchamp et al. 2015). Mutual respect, risk-taking, a determination to improve, and professional, progressive discourse are factors cited as essential for effective professional learning (Schuck, Aubusson and Buchanan 2008). However these conditions need to be carefully scrutinised, with consideration given to the purpose of that professional learning.

Earley and Bubb (2004) distinguish 'hard' economic utilitarianism, where professional learning addresses the strategic goals of an institution, from a 'softer' developmental humanism in which professional learning caters for valued, confident and motivated staff. This bifurcation is helpful when considering a further distinction made by Lipowski et al. (2011) between two forms of professional learning. First: in-service programmes are organised formal programmes for practitioners within the institutions where they work, considered by some to be the primary way in which they receive continuing support (Loucks-Horsley et al. 1997). Second: continuous experiential learning accommodates the more informal learning opportunities that contribute to everyday professional practice, the importance of which cannot and should not be underestimated when trying to understand the work teacher educators do in different national locations and the professional support they need (MacPhail et al. 2014). While recognising the contestability of both terms, the authors of this article use both professional development and professional learning as portmanteau terms to describe the formal and informal processes that enable teacher educators to improve their professional practice throughout their careers, with a commitment to transform education for the better (Czerniawski et al. 2017). 
Previous attempts to describe teacher educators' work (see Swennen, Jones and Volman 2010; Lunenberg, Dengerink and Korthagen 2014) have cited a variety of roles, each of which may require professional development: teaching, coaching, facilitation of collaboration between diverse organisations and stakeholders, assessment, 'gatekeeping', curriculum development, critical inquiry and research. The lack of induction into these roles experienced by so many teacher educators is well documented (Murray, Czerniawski and Barber 2011; Kosnik et al. 2015). However, Griffiths, Thompson and Hryniewicz (2014) make a distinction between two groups of university-based teacher educators, adding further complexity. Teacher educators from Anglophone countries often move to universities having previously taught in schools. A second group exists from countries where teacher educators are drawn mainly from academic disciplines often lacking practical teaching experience (Griffiths, Thompson and Hryniewicz 2014). Both groups are likely to encounter different transitional experiences influencing their professional learning needs.

\section{Three national contexts}

As mentioned earlier this study focuses on three Anglophone countries in Europe. Each shares certain commonalities including the rationalization, restructuring and reconfiguration of teacher education. But they are also distinct in having their own discrete education systems. While many other similarities exist, such as teacher education historically being largely, or solely, located in Colleges of Education, over the past twenty-five years their paths have diverged albeit within seemingly unstable policy contexts. The paragraphs which follow provide a brief overview of the teacher education provision in each of these three countries followed by an analysis of the perceived professional learning needs of university-based teacher educators located each of the three countries.

\section{England}

Within an economic context of a recent global recession, exacerbated by the anticipated UK withdrawal from the European Union, the current state of England's teacher education is challenging and reflects, in part, the continued dominance of ministerial views espousing a commitment to the marketplace, supply-side economics and fiscal restraint (Gove 2013; Morgan 2015). University-based teacher educators are a broad and heterogeneous occupational group (Murray, Czerniawski, and Barber 2011). There are commonalities in entry requirements and qualifications in that higher education-based teacher educators, teaching pre-service (or initial teacher education (ITE)) courses, are nearly always qualified teachers with substantial experience of school teaching. Many enter higher education without doctorates or personal research experience (although they may have undertaken small-scale practitioner research and scholarship as part of their professional development in schools). Following relatively common contractual processes for the appointment of academic faculty, the majority of teacher educators would undertake a short 'probation' before being appointed to permanent posts. Some universities have recently created 'teaching only' posts with no contractual obligation to undertake research, but the majority still require faculty to engage in research and scholarship.

The institutions offering teacher education in England range from long-established, researchintensive universities, riding high in international research league tables, to newly established teaching-intensive universities (often distinguished as 'new' universities). The category 'new university' includes a broad spectrum of institutions, including some that gained university status only after 2000. The schools of education within these differing types of university vary greatly in the ways in which they instantiate the discourses and practices of teacher education, and the 
teacher educators within these departments face varying expectations in teaching, management activities and research. The tension generated by being a teacher educator and researcher in the English context is one exacerbated by the Research Excellence Framework ('REF'), an impact evaluation that assesses the research of British higher education institutions. This evaluation, carried out every five to six years, pressurises teacher educators in many higher education institutions to generate high impact research, three to four star quality publications and successful prestigious research grants applications. Previous research (Maguire 2000; Murray 2012) has also indicated that teacher educators often have heavy workloads, teach long hours in universities and schools, and undertake high levels of student support. Other research has documented the process of professional learning involved in the dominant model of 'expert teachers' becoming teacher educators in universities/Higher Education and as a result undertaking a reconstruction process of pedagogy and identity (Murray and Male 2005; Boyd and Harris 2010).

England is currently undergoing a seismic shift in the ways in which student teachers are being prepared for their future careers, leaving many university-based teacher educators facing career uncertainty and insecurity (DfE 2010; McNamara, Murray and Phillips 2017). Indeed, the very term 'student' is problematic when there has been, over the last decade, a substantial increase in the numbers of salaried, unqualified teachers trained 'on the job'. In 2013 the coalition government introduced 'Schools Direct' as part of its reorganisation of ITE. Schools Direct is the latest school-led teacher-training pathway in which schools recruit their own trainees, becoming the new 'gatekeepers' to the profession. The assumption is that these 'employees' (Schools Direct exists in salaried and non-salaried pathways) will, in most cases, take up permanent positions with the school on completion of their training. Both Schools Direct and School-Centred Initial Teacher Training (SCITT) represent a significant threat to higher education institutions (HEIs) through decreasing student numbers (and therefore income), the extent to which research remains viable within the academy, and the value placed on different forms of professional learning.

\section{Ireland}

Teacher education in Ireland has been significantly reconfigured over the last decade due to a number of factors (Vanassche et al. 2015). First, the Teaching Council (professional regulatory body) was established in 2006. Second, in response to poor learning outcomes among children, measured in PISA (Programme for International Student Assessment) 2009 (DES 2011), there has been the issuing of new guidelines for all teacher education programmes (Teaching Council 2011a, 2011b) and, as Conway and Murphy (2013) point out, the re-design since then of all ITE programmes. Third, as part of a wider rationalisation of higher education, a radical restructuring of the way in which teacher education is made available in Ireland was initiated (Hyland 2011; Sahlberg, Furlong and Munn 2012). While teacher education has become a policy priority in the last decade, the professional preparation of those working in teacher education has not been a focus. The multiple professional pathways into teacher education have remained similar to a historic pattern. However, with the recent ongoing Government-initiated restructuring and system rationalisation, the goal of which is to reduce the number of teacher education providers from nineteen to six, and to concentrate teacher education in these six sites as 'centres of excellence', there have been inevitable implications for the status, work and future professional preparation of those working in teacher education.

This recent policy context has re-framed the role of teacher education and research. Significantly, the joint influence of the more complete universitisation of teacher education recommended in the Sahlberg Report (Sahlberg, Furlong and Munn 2012), along with increased rankings pressure on universities, has meant that there is increasing pressure on teacher education academics as 
they work in HEIs to acquire a $\mathrm{PhD}$ and publish in peer-reviewed research outlets. Contextualising this is important in terms of patterns of research practice in teacher education. While there have been no studies or reviews, trends can be identified. First, there has been a growth of research on teacher education in Ireland over the last decade, with publication of peerreviewed journal articles, reports and small-scale collaborations. Second, while much of the research on teacher education has comprised small-scale studies within individual programmes, or sometimes between programmes in different institutions (e.g. SCoTENS (Standing Conference on Teacher Education, North and South)), there have been some larger studies, as commissioned reports which have provided more system-level insights on teacher education. Third, the focus of research has been mainly on ITE, with some focus on CPD and very little, until recently, on induction (Conway et al. 2009; Smyth et al. 2016). Taking the above observations together, the opportunities to learn and experience research as a teacher educator arise typically within one's own institution. The proportion of staff involved, duration of involvement, types and foci of studies and the extent to which such research is seen as central to teacher educators' professional institutional profiles are unknown. Anecdotal evidence suggests significant differences between institutions in the standing of research on teacher education. Despite the current policy focus on the quality of ITE programmes, there has been a relative lack of focus on teacher educators' professional learning as evidenced in the review of primary (Kellaghan 2002) as well as in postprimary teacher education (Byrne 2002). As such, the prioritisation of teacher education in the last decade, and even more so in the last five years, is evident in the significant Teaching Council prioritisation of a labour-intensive accreditation of all ITE programmes since the publication of binding national ITE regulations by the Council in 2011.

\section{Scotland}

The transition of teacher education, over the past 20 years, from being largely located in colleges of education to being incorporated into universities (Gray and Weir, 2014) provides an unstable context for teacher educators' professional learning. As in many other countries, teacher educators in Scotland are recruited from teachers working in schools. Other than having postgraduate qualifications, such as a Masters or, occasionally, a doctorate, most staff recruited to teacher education posts have little experience in higher education, and employment in a sector that is, in most disciplines, overwhelmingly associated with research. Previously in the colleges of education, while some research had taken place, 'there was no requirement or expectation on lecturers involved in teacher training to engage with research activities in addition to teaching trainees and providing continuing professional development courses for teachers' (H. Smith, 2014, 23). In Scotland, the General Teaching Council for Scotland (GTCS) largely controls the requirements for all ITE provision, with the expectation that most staff involved in ITE in higher education institutions are GTCS-registered, and thus, by implication, former teachers. The GTCS has also recognised the importance of research for the teaching profession, and this recognition is clearly stated in the various GTCS standards for Registration (GTCS, 2012c), Career-Long Professional Learning (GTCS, 2012b) and Leadership and Management (GTCS, 2012a). There are also clear expectations of teachers engaging in and with research within the professional standards for teachers; standards to which teacher educators need to adhere to maintain their professional GTCS registration. For example, the Standard for Career-long Professional Learning has specific expectations around professional enquiry: 'develop and apply expertise, knowledge and understanding of research and impact on education; develop and apply expertise, knowledge, understanding and skills to engage in practitioner enquiry to inform pedagogy, learning and subject knowledge; lead and participate in collaborative practitioner enquiry' (GTCS, 2012: 10). While some form of engagement with research is expected in the GTCS standards for teachers, including teacher educators, this is further reinforced in Higher Education where many teacher educators will be expected to meet the requirements for the Research Excellence Framework. Where research is specified as a part of the contract of 


\section{employment of a teacher educator in a university, they will be expected to meet the criteria for inclusion in the REF exercise. In the 2014 REF all the universities in Scotland that had teacher education programmes at that time made a submission to the REF exercise.}

\section{Research design}

Participants in this study were recruited through their institutions and professional networks. A total of 157 higher-education based teacher educators in England, 54 in the Republic of Ireland and 61 in Scotland responded to a survey from a larger study, carried out by InFo-TED, of 1,158 teacher educators (Czerniawski, MacPhail and Guber 2017) working in higher education institutions (HEIs) in Belgium, Ireland, Israel, the Netherlands, Norway and the UK. This larger study (details and survey questions available on request by emailing the corresponding author) provided an international and comparative-needs analysis of their professional learning needs. In this article we examine three Anglophone countries within the InFo-TED network, namely England, the Republic of Ireland and Scotland. The study addresses two research questions:

1. What professional learning activities do higher education-based teacher educators value?

2. How best can these activities be realised?

Professional learning needs were assessed by a questionnaire that had four sections: professional learning preferences (31 items); factors considered before a professional learning activity is engaged in (8 items); research dispositions and experience (4 items); role description and background information (28 items). Examples of questions from each of the four sections include:

- As a teacher educator, to what extent are you personally satisfied with the professional learning opportunities you have experienced to date?

- To what extent do the following factors influence your engagement in professional learning? (copy of survey available on request indicating response choices)?

- The following statements concern the extent to which you actively conduct research. Please indicate the most applicable answer to each statement (copy of survey available on request indicating survey statement choices)

- If you are a qualified teacher please state your type(s) of qualification(s) (if you are not a qualified teacher please tick 'not applicable')

Within the same questionnaire, participants rated on a Likert response scale, ranging from 1 (= not at all) to 6 (= very much), their level of satisfaction with the professional learning opportunities they have had (1 item), their degree of interest in further professional learning (1 item) and their interest in specific professional learning options (27 items). Participants also provided qualitative responses to two survey questions - 'What are your two most important professional learning needs?' and 'What professional learning opportunities would best meet these needs?'

The authors acknowledge the limitations of an article of this nature, not least the extent to which it is able to address the in-depth specificities of teacher educators' professional learning on a country-by-country basis. It should also be noted that the number of participants are not equally divided amongst the three countries (with 58\% coming from England alone) and this unequal division has the potential to skew the data. However, the ongoing study, reported here, begins to address the lack of research into the professional development of teacher educators and, moreover, to determine what is effective in supporting them in their professional growth (Lunenberg, Dengerink and Korthagen 2014). Follow-up interviews are underway with a sample of participants in each of the participating InFo-TED countries that will, in future publications, provide greater insight into the relationship between professional learning opportunities and the resulting learning outcomes. 


\section{Findings}

\section{Teacher educator professional demographics}

Table 1 indicates that the majority of participants in this study were female, reflecting the gendered nature of this profession. This sample tends to be older than school-based colleagues (although participants from Ireland tend to be younger than their Scottish and English universitybased counterparts) and most have worked as teacher educators for a considerable period of time (mean length 10-14 years). However, these age separations do not necessarily imply proportionately greater experience or status within the university - rather that many teacher educators are former teachers and as 'second order practitioners' (Murray and Male 2005) move into Higher Education/University after a first and sometimes second career as teachers. While percentages vary, it is notable that the majority of participants are actively engaged in research (including the writing up of those findings). It is also notable that significantly higher numbers of participants from the Irish sample possess doctorates and are actively involved in research.

\section{[Table 1 near here]}

\section{Professional learning activities valued by teacher educators}

Most teacher educators in all locations expressed only moderate satisfaction with their experiences of professional learning to date (Table 2). However, many activities were considered highly valuable, including those associated with research, personal reading, informal learning conversations with colleagues and opportunities to develop pedagogy. Of less value were those activities associated with on-line learning, observations by colleagues, peer coaching and training activities undertaken within the employer institution. It is worth noting that there is a level of consistency in response to each professional learning activity across the three countries.

\section{[Table 2 near here]}

\section{Areas requiring further professional learning}

The numbers highlighted in bold (Table 3) represent the top three priorities for further professional learning identified in the three national contexts. Common to all was a need to be updated in the latest developments in teacher education. English and Scottish teacher educators prioritised curriculum development while participants from Scotland and Ireland emphasised areas associated with assessment requiring further professional learning. Of least importance in all three locations were specialisation in academic administration, coaching and mentoring of student teachers and reviewing for journal articles and conference abstracts.

\section{[Table 3 near here]}

Table 4 conveys that the three most influential factors determining all teacher educators' engagement in professional learning were: the extent to which activities are associated with teaching and learning; knowledge of who the providers are; and the availability of other staff to cover any teaching (and other work-related activities) while attending professional learning 
opportunities. The data would also appear to show that a rise in salary (if deemed potentially associated with the professional learning activity) is not considered an influential factor in engagement.

\section{[Table 4 near here]}

As mentioned earlier, participants also provided qualitative responses to two survey questions - 'What are your two most important professional learning needs?' and 'What professional learning opportunities would best meet these needs? Conscious that no room exists in this paper to fully present the comments that were collected in response to these questions the section below provides the reader with a flavour of the responses. It is anticipated that these will be explored in more depth in future papers related to the study.

There were some notable similarities and differences in the three sample's responses to the qualitative survey question that sought their two most important professional learning needs. The English sample consistently reported research skills/activities and keeping abreast of new subject knowledge, pedagogies and curriculum changes/development. These two responses were almost twice as popular as the next listed professional learning need of writing for publication. Keeping abreast of the use of technology in teaching and securing funding for research projects were the next level of popular requests for professional learning from the English sample. Keeping abreast of innovative teaching methodology and finding time to conduct research and writing were the most frequent professional learning needs noted by the Irish sample. The use of technology was a third (but less frequent) request from the Irish sample. With respect to the Scottish sample, teacher educators consistently noted keeping abreast of new subject knowledge, pedagogies and curriculum changes/development and the opportunity to be involved in scholarly writing. An increased opportunity to undertake general research skills/activities were the next frequently noted list of professional learning needs.

There was a noticeable similarity between England and Scotland when the respective samples were asked what professional learning needs would best meet their needs. Both samples overwhelmingly supported access to more collaboration, which in both cases, was more than twice as popular as the next listed preferable professional learning opportunities. These included requests for collaboration with colleagues in their own institution or external to their institution; becoming part of a network of teacher educators; being allocated a mentor/'buddy' from which they could have a more intense learning experience; and informal forums to share thoughts and practices on a regular basis. A variety of skill-based opportunities such as workshops, seminars and more formalized courses was the next most frequent response for the Scottish and English samples with the latter noting attendance at conferences as another frequent request. An opportunity for upskilling opportunities such as workshops and seminars was the most frequently noted professional learning need that would meet the needs of the Irish sample, although there little consensus existed in relaton to what such opportunities should focus on.

\section{Discussion}


As stated earlier the starting point for teacher educators' professional development lies in their practice, which is positioned within global, regional, national and local policy contexts. Over the last 20 years, the dominant policy agenda in Western democracies has been to open up teacher education to market forces, deregulation and cost-cutting (Davey 2013). In the three participating countries that this study addresses this agenda has led to greater rationalization, restructuring and reconfiguration of teacher education with inevitable implications for professional learning. However nowhere are these characteristics more prevalent or powerfully articulated than in England. Here, schools and universities have had to navigate their way through increasing competition, accountability and external evaluation. Many of the participants in England noted, for example, how this has restricted time and access to professional networks, learning activities and research-related activity. One possible victim of this expansive sociopolitical and economic policy agenda might, therefore, be access to professional and social capital (Hargreaves and Fullan 2013), used here to describe capital associated with the complex sets of relationships between universities and schools; publishers and examination boards; teachers and teacher educators; students and 'trainees'.

Two points of commonality across the three countries are worth highlighting. First, entry into teacher education is, as the data suggest, most likely a mid-career opportunity rather than a longterm plan initiated early in a career. It is therefore important to acknowledge that while midcareer entrants generally have significant professional experience in schools, this may not encompass research activity. While the majority of participants in this study came under this category, they also work alongside younger colleagues with, often, stronger research backgrounds. For both groups to effectively share practices and experiences in future, further work is needed in the organisational cultures found in many HEIs despite a recent growth in the levels of collaborative support for neophyte university employees (Laudel and Glaser 2008; Van der Klink et al. 2017). This need for opportunities to generate critical, collaborative professional learning conversations has been supported in the literature (Hoban 2002; Loughran 2014), with research beginning to explore professional learning/development communities for teacher educators (Hadar and Brody 2010; MacPhail et al. 2014). This study builds on this literature, emphasising the ways in which most teacher educators from all three countries, as former teachers and/or researchers, want to be part of a collaborative community where they feel supported, listened to, and can share their practices and experiences. Evidence already exists highlighting the ways in which teacher educators seek out, and work and publish with researchers from other disciplines on matters related to the curriculum and pedagogy (Hammond and McCallum 2009; Prima 2014). However, the extent to which collaborative communities can operate successfully is dependent on available human and material resources. Regardless of the type of development needed, or whether teacher educators came from a school-teaching or 'academic' [sic] background, participants in this study expressed a strong preference for professional learning opportunities that are continuous and experiential (e.g., working collaboratively with colleagues/experienced researchers; being mentored; being part of a team). Allocating sufficient, designated time for proper induction and professional learning would, therefore, enable policy-makers and higher education institutions to capitalise on mid-career entrants and encourage teacher educators to develop a more diversified, balanced, integrated professional profile rather than expecting them to achieve this alone.

Second, the increased national and international rankings pressure on universities has meant greater pressure on academics in teacher education, as they work to acquire a doctorate and publish in peer-reviewed research outlets (Stern 2016). Tack and Vanderlinde $(2014,314$ ) assert that developing a researcherly disposition requires 'teacher educators to intentionally study their practice and make explicit the developed knowledge on a local and public level'. If teacher educators' lack of confidence in their research and writing skills, and the lack of time are barriers for teacher educators being teacher educator-researchers, then opportunities need to be created to embed research within the day-to-day practice of a teacher educator. Acknowledgement of these barriers is important, not least, when considering the future supply chain to universities of 
teacher educators who, as former schoolteachers, may also come from countries adopting England's increasingly school-based, occupational teacher training model rather than a more university-structured ITE programme. In the Scottish professional standards for teachers, there are clear expectations of teachers engaging in and with research, standards to which teacher educators need to adhere if they are to maintain their registration with the GTCS as set out above.

These data are an early exploration of how best to support the professional development needs of university-based teacher educators. Such a development cannot be short-term or rooted in the 'now' but must seek to sustain future generations of teachers entering and, hopefully, remaining in the profession. The contribution that universities can make to their development must not be underestimated. It is essential that we do all we can to create further opportunities to learn from the very best practices in professional learning in teacher education in different local, national, regional and global contexts. We have written elsewhere (Czerniawski, Kidd and Murray, forthcoming) about our fears regarding the potential diminution of the role research plays in the quality of ITE, teacher educators' professional learning and teacher professionalism. Gewirtz (2013) argues that the danger in talking about research-informed teacher education is that this reinforces a reductionist, techno-engineering model of teaching where teachers, uncritically, implement 'what works'. This study offers complex hope by showing the value teacher educators place on the role research plays in the evaluation of their own professional practice and in the education of future generations of teachers.

\section{Concluding thoughts}

Findings from this study would indicate that most teacher educators in all three locations place extremely high value on further professional learning and the role that research can play in its development. However, placing high value on something is not the same as engaging in it. The authors of this paper therefore argue that enacting these particular professional values is crucial if we are to avoid the reductionism inherent in what McNamara and Murray (2013) have identified as an ideologically driven understanding of teaching as essentially only a 'craft' rather than a complex and fundamentally intellectual activity. The sorcerer's apprentice found himself in deep water mimicking the actions of his master without the requisite skills, knowledge and attributes, developed over time through scholarship and practice. One of the many triumphs of the European Union has been the increase in attention given to the importance of teacher educators and their scholarly capital, as 'public intellectuals' (Cochran-Smith 2006; European Commission 2015), in the development of the teaching profession. It will be a tragedy for teacher educators if Brexit causes a domino effect reversing this process and, in so doing, not only reduces opportunities for further professional learning, but perpetuates this overly simplistic and antiintellectual understanding of that apprenticeship.

Acknowledgements: Special thanks to Professor Jean Murray at the University of East London, Jenny Barksfield, Hanne Tack and the reviewers of this journal for their invaluable contributions during the writing, editing and amendments stages of this publication.

\section{References}

Bates, T., A. Swennen, and K. Jones. 2011. The Professional Development of Teacher Educators. London: Routledge.

Beauchamp, G., L. Clarke, M. Hulme, M. Jephcote, A. Kennedy, G. Magennis, and I. Menter. 2015. Teacher Education in Times of Change. Bristol: Policy Press. 
Berry, M. 2013. “Teacher Educators' Professional Learning: 'You're More or Less on Your Own."' Paper presented at the 16th biennial conference of ISATT (International Study Association on Teachers and Teaching), Ghent, Belgium, July 2-7.

Boyd, P. and Harris, K. 2010. "Becoming a university lecturer in teacher education: Expert school teachers reconstructing their pedagogy and identity" Professional Development in Education 36 (1): 9-24.

Byrne, K. 2002. Advisory Group on Post-Primary Teacher Education. Dublin: Department of Education and Science.

Cochran-Smith, M. 2006. Policy, Practice and Politics in Teacher Education. Thousand Oaks, CA: Corwin Press.

Conway, P. F., Murphy, R., Rath, A., and K. Hall, 2009. Learning to teach and its implications for the continuum of teacher education: A nine-country cross-national study. Report commissioned by the Teaching Council (Ireland). Available from: http://www.teachingcouncil.ie/en/Publications/Research/Documents/Learning-toTeach-and-its-Implications-for-the-Continuum-of-Teacher-Education.pdf

Conway, P. F., and Murphy, R. 2013. "A rising tide meets a perfect storm: new accountabilities in teaching and teacher education in Ireland” Irish Educational Studies, 32 (1): 11-36.

Czerniawski, G., W. Kidd, and J. Murray. Forthcoming. "'We are all teacher educators now': understanding school-based teacher educators in times of change in England." In International Research, Policy and Practice in Teacher Education: Insider Perspectives, edited by J. Murray, J. A. Swennen, and C. Kosnik, Dordrecht: Springer Academic Publishers.

Czerniawski G., A. MacPhail, and A. Guberman. 2017. "The Professional Development Needs of Higher Education-Based Teacher Educators: An International Comparative Needs Analysis." European Journal of Teacher Education 40 (1), 127-140.

Davey, R. 2013. The Professional Identity of Teacher Educators - Careers on the Cusp? New York: Routledge.

Department of Education and Skills [DES]. 2011. Literacy and Numeracy for Learning and Life: The National Strategy to Improve Literacy and Numeracy among Children and Young People 2011-2020. Dublin: DES. Available from: http://www.education.ie/en/Press-

Events/Events/Literacy-and-Numeracy/

DfE (Department for Education). 2010. The Importance of Teaching. The Schools White Paper 2010. Available

at: www.gov.uk/government/uploads/system/uploads/attachment data/file/175429/CM7980.pdf

Earley, P., and S. Bubb. 2004. Leading and Managing Continuing Professional Development: Developing Teachers, Developing Schools. London: Sage/Paul Chapman.

European Commission. 2015. Strengthening Teaching in Europe: New Evidence from Teachers Compiled by Eurydice and CRELL, June 2015. Available from: http://ec.europa.eu/education/library/policy/teaching-profession-practices en.pdf.

Gewirtz, S. 2013. "Developing teachers as scholar-citizens, reasserting the value of university involvement in teacher education." In Learning to Teach: Exploring the History and Role of Higher Education in Teacher Education, edited by L. Florian and N. Pantic. London: Higher Education Academy. 
Goodwin, A. L., Smith, L., Souto-Manning, M., Cheruvu, R., Tan, M. Y., Reed, R., and Taveras, L. 2014. "What Should Teacher Educators Know and be Able to Do? Perspectives from Practicing Teacher Educators." Journal of Teacher Education May, 1-19. doi:10.1177/0022487114535266.

Gove, M., 2013. "I refuse to surrender to the Marxist teachers hell-bent on destroying our schools: Education Secretary berates 'the new enemies of promise' for opposing his plans," Daily Mail, March 23.

Gray, D. (2010). "International Perspectives on Research in Initial Teacher Education and Some Emerging Issues." Journal of Education for Teaching 36 (4), 345-351. doi: $\underline{10.1080 / 02607476.2010 .513839 .}$.

Gray, D., and Weir, D. (2014). "Retaining Public and Political Trust: Teacher Education in Scotland." Journal of Education for Teaching 40 (5), 569-587. doi:10.1080/02607476.2014.956541.

Griffiths, V., S. Thompson, and L. Hryniewicz. 2014. "Landmarks in the Professional and Academic Development of Mid-career Teacher Educators". European Journal of Teacher Education 37 (1): 74-90.

GTCS (General Teaching Council for Scotland). 2012a. The Standard for Career-Long Professional Learning: Supporting the Development of Teacher Professional Learning (December), $10 \mathrm{pp}$. Retrieved from http://www.gtcs.org.uk/web/files/the-standards/standard-for-career-longprofessional-learning-1212.pdf.

GTCS. 2012b. The Standards for Leadership and Management: Supporting Leadership and Management Development. Retrieved from http://www.gtcs.org.uk/web/FILES/thestandards/standards-for-leadership-and-management-1212.pdf.

GTCS. 2012c. The Standards for Registration: Mandatory Requirements for Registration with the General Teaching Council for Scotland (December), 19 pp. Retrieved from http://www.gtcs.org.uk/web/Files/the-standards/standards-for-registration-1212.pdf.

Hadar, L., and D. Brody. 2010. "From Isolation to Symphonic Harmony: Building a Professional Development Community among Teacher Educators." Teaching and Teacher Education 26, 1641-1651.

Hammond C., McCallum F. 2009. Interdisciplinarity: bridging the university and field of practice divide. Australian Journal of Teacher Education. 34 (2): 50-63.

Hargreaves, A., and M. Fullan. 2013. “The Power of Professional Capital.” JSD 34 (3): 36-39.

Hoban, G. F. 2002. Teacher Learning for Educational Change: A Systems Thinking Approach. Buckingham: Open University Press.

Hyland, A. 2012. A review of the structure of teacher education provision in Ireland: A paper for the international review team. Dublin: Higher Education Authority. Available from: www.hea.ie/files/AineHylandFinalReport.pdf

Kellaghan, T. 2002. Preparing Teachers for the 21st Century: Report of the Working Group on Primary Preservice Teacher Education. Dublin: Department of Education and Science.

Kennedy, A. 2005. "Models of continuing professional development: a framework for analysis". Journal of In-service Education. 31 (2), 235-250.

Kosnik, C., P. Dharmashi, C. Miyata, Y. Cleovoulou, and C. Beck. 2015. "Four Spheres of Knowledge Required: An International Study of the Professional Development of Literacy/English Teacher Educators." Journal of Education for Teaching 4 (1), 52-77. 
Laudel G., Glaser J., 2008. From apprentice to colleague: the metamorphosis of Early Career Researchers. Higher Education. 55: 337-406.

Lipowski, K., D. Jorde, M. Prenzel and T. Seidel. 2011. "Expert Views on the Implementation of Teacher Professional Development in European Countries." Professional Development in Education 37 (5): 685-700.

Loucks-Horsley, S., P. W. Hewson, N. B. Love and K. E. Stiles. 1997. Designing Professional Development for Teachers of Science and Mathematics. Thousand Oaks, CA: Corwin.

Loughran, J. 2014. “Professionally Developing as a Teacher Educator.” Journal of Teacher Education 65 (4), 271-283.

Lunenberg, M., J. Dengerink and F. Korthagen. 2014. The Professional Teacher Educator: Roles, Behaviour, and Professional Development of Teacher Educators. Rotterdam: Sense Publishers.

Lunenberg, M., and M. Willemse (2006). "Research and Professional Development of Teacher Educators." European Journal of Teacher Education 19 (1), 81-98. doi:10.1080/02619760500478621.

McNamara, 0., and J. Murray. 2013. "The School Direct programme and its implications for research informed teacher education and teacher educators." In Learning to Teach: Exploring the History and Role of Higher Education in Teacher Education, edited by L. Florian and N. Pantic, ${ }^{* * *}$ ***. London: Higher Education Academy, London.

McNamara, O., J. Murray, and R. Phillips. 2017. Policy and Research Evidence in the 'Reform' of Primary Initial Teacher Education in England. Cambridge Primary Review Trust Research Survey 10 (new series). Cambridge: CPRT.

MacPhail, A., K. Patton, M. Parker, and D. Tannehill. 2014. "Leading by Example: Teacher Educators' Professional Learning through Communities of Practice." Quest 66: 39-56.

Maguire, M. 2000. "Inside/outside the Ivory Tower: Teacher Education in the English Academy." Teaching in Higher Education 5 (2), 149-165.

Morgan N. (2015) Speech Delivered by the Secretary of State for Education on 21 st January 2015 at the BETT show, Excel London: Available at: https://www.gov.uk/government/speeches/nicky-morgan-speaks-at-the-2015-bett-show.

Murray, J. 2012. "Towards the Re-articulation of the Work of Teacher Educators in Higher Education Institutions in England." European Journal of Teacher Education 31 (1), 17-34.

Murray, J., and T. Male. 2005. "Becoming a Teacher Educator: Evidence from the Field." Teaching and Teacher Education 21: 125-142.

Murray, J., G. Czerniawski, and P. Barber. 2011. “Teacher Educators' Identities and Work in England at the Beginning of the Second Decade of the Twenty-First Century." Journal of Education for Teaching 37 (3): 261-277.

Prima R. (2014), Value orientations in professional training of teacher-educators. Rozprawy Społeczne, 4 (VIII), s. 13-15. Available at: http://rozprawyspoleczne.pswbp.pl/pdf/rs $\mathrm{nr} 4$ art 2.pdf

Sahlberg, P., J. Furlong, and P. Munn. 2012. Report of the International Review Panel on the Structure of Initial Teacher Education Provision in Ireland: Review Conducted on Behalf of the Department of Education and Skills. Dublin: Higher Education Authority of Ireland.

Schuck, S., P. Aubusson, and J. Buchanan. 2008. "Enhancing Teacher Education Practice through Professional Learning Conversations." European Journal of Teacher Education 31 (2): 215-227. 
Smith, H. (2014). "Teacher education in Scotland: the challenges facing teachers and teacher educators within a rapidly changing education landscape." In Teacher Educators and Teachers as Learners: International Perspectives, edited by P. Boyd, A. Szplit, and Z. Zbróg, 21-36. Kraków: Zuzanna.

Smyth, E., Conway, P., Leavy, A., Darmody, M., Banks, J., and Watson, D. 2016. Review of the Droichead Teacher Induction Pilot Programme. Dublin/Maynooth: ESRI/Teaching Council. Available from: https://www.education.ie/en/Publications/Education-Reports/Review-of-the-Droichead-TeacherInduction-Pilot-Programme-Executive-Summary.pdf

Stern, A. 2016. Building on Success and Learning from Experience - An Independent Review of the Research Excellence Framework. Crown copyright: ref: IND/16/9.

Swennen, A., K. Jones, and M. Volman. 2010. "Teacher Educators: Their Identities, Sub-Identities and Implications for Professional Development." Professional Development in Education 36 (1-2), 131-148.

Tack, H., and R. Vanderlinde. 2014. “Teacher Educators' Professional Development: Towards a Typology of Teacher Educators' Researcherly Disposition." British Journal of Educational Studies, 62 (3), 297-315. doi: 10.1080/00071005.2014.957639.

Teaching Council. 2011a. Initial Teacher Education: Criteria and Guidelines for Programme Providers. Available from: http://www.teachingcouncil.ie/en/Publications/TeacherEducation/Initial-Teacher-Education-Criteria-and-Guidelines-for-Programme-Providers.pdf

Teaching Council. 2011b. Initial Teacher Education: Strategy for the Review and Professional Accreditation of Existing Programmes. Available from: http://www.teachingcouncil.ie/initialteacher-education-ite/review-and-professional-accreditation-of-existing-programmes-ofite.460.html

Van der Klink M., Kools Q., Avissar G., White S., and Sakata T. 2017. Professional development of teacher educators: what do they do? Findings from an explorative international study. Professional Development in Education. 43 (2): 163-178.

Vanassche, E., Rust, F., Conway, P. F., Smith, K., Tack, H., Vanderlinde, R. (2015) “InFo-TED: Bringing Policy, Research, and Practice Together around Teacher Educator Development" In: Cheryl J. Craig, Lily Orland-Barak (eds). International Teacher Education:Promising Pedagogies (Part C), 341-364. London: Emerald Group

Zeichner, K. (1999). "The New Scholarship in Teacher Education." Educational Researcher 28 (9), 4-15. doi:10.3102/0013189X028009004.

Table 1: Teacher educator professional demographics

\begin{tabular}{|l|l|l|l|}
\hline & England (n=157) & Ireland (n=54) & Scotland (n=61) \\
\hline Gender of workforce & Female 69\%; male 31\% & Female 67\%; male 33\% & Female 79\%; male 21\% \\
\hline $\begin{array}{l}\text { Largest and second- } \\
\text { largest age brackets }\end{array}$ & $\begin{array}{l}41 \% \text { aged 45-54; 32\% } \\
\text { aged 55-64 }\end{array}$ & $\begin{array}{l}35 \% \text { aged 45-54; 22\% } \\
\text { aged 35-44 }\end{array}$ & $\begin{array}{l}41 \% \text { aged } 45-54 ; 30 \% \\
\text { aged 55-64 }\end{array}$ \\
\hline
\end{tabular}




\begin{tabular}{|l|l|l|l|}
\hline $\begin{array}{l}\text { \% of sample who were } \\
\text { ex-teachers }\end{array}$ & 96 & 74 & 96 \\
\hline $\begin{array}{l}\text { Mean length of time as } \\
\text { teacher educator }\end{array}$ & 10 years & 14 years & 10 years \\
\hline $\begin{array}{l}\text { Highest academic } \\
\text { qualification }\end{array}$ & $\begin{array}{l}11 \% \text { first degree; 53\% } \\
\text { Masters; 36\% doctorate }\end{array}$ & $\begin{array}{l}17 \% \text { Masters; 83\% } \\
\text { doctorate }\end{array}$ & $\begin{array}{l}18 \% \text { first degree; } 40 \% \\
\text { Masters; } 42 \% \text { doctorate }\end{array}$ \\
\hline $\begin{array}{l}\text { \% of sample working full } \\
\text { time }\end{array}$ & 78 & 51 & 87 \\
\hline $\begin{array}{l}\text { \% of sample on } \\
\text { permanent contracts }\end{array}$ & 93 & 80 & 89 \\
\hline $\begin{array}{l}\text { \% of sample actively } \\
\text { involved in research }\end{array}$ & 81 & 95 & 76 \\
\hline
\end{tabular}

Table 2: Professional learning activities valued by teacher educators (expressed as mean value 1-6)

\begin{tabular}{|l|l|l|l|}
\hline & England (n=157) & Ireland (n=54) & Scotland (n=61) \\
\hline $\begin{array}{l}\text { Overall satisfaction with experiences of } \\
\text { professional learning to date }\end{array}$ & 3.62 & 3.80 & 3.42 \\
\hline Personal reading & $\mathbf{5 . 1 4}$ & $\mathbf{5 . 0 0}$ & $\mathbf{5 . 3 6}$ \\
\hline $\begin{array}{l}\text { Informal learning conversations with } \\
\text { colleagues }\end{array}$ & 4.93 & 4.81 & 5.11 \\
\hline $\begin{array}{l}\text { Visits to other schools/teacher education } \\
\text { institutions }\end{array}$ & 4.84 & 4.87 & 4.39 \\
\hline Participation in professional organisations & 4.70 & 4.56 & 4.50 \\
\hline Action research/Practitioner research & 4.75 & 4.61 & 4.48 \\
\hline Secondments and sabbaticals & 4.46 & 4.63 & 4.50 \\
\hline Role of research when studying own practice & $\mathbf{5 . 5 0}$ & $\mathbf{5 . 3 0}$ & $\mathbf{5 . 4 5}$ \\
\hline $\begin{array}{l}\text { Extent to which research is essential for the } \\
\text { profession }\end{array}$ & $\mathbf{5 . 5 4}$ & $\mathbf{5 . 3 3}$ & $\mathbf{5 . 3 1}$ \\
\hline On-line learning & 3.44 & 3.89 & 3.98 \\
\hline $\begin{array}{l}\text { Training activities undertaken within the } \\
\text { institution of employment }\end{array}$ & 3.84 & 4.13 & 4.03 \\
\hline Observations by colleagues & 3.82 & 3.98 & 3.367 \\
\hline Developing own pedagogy & $\mathbf{5 . 1 4}$ & 4.96 & $\mathbf{5 . 1 3}$ \\
\hline International exchange visits & 4.32 & 4.67 & 4.33 \\
\hline Academic writing & 4.36 & 4.56 & 3.17 \\
\hline Peer coaching & & 3.04 & \\
\hline
\end{tabular}


Table 3: Areas requiring further professional learning (expressed as mean value 1-6)

\begin{tabular}{|c|c|c|c|}
\hline & $\begin{array}{l}\text { England } \\
(n=157)\end{array}$ & $\begin{array}{l}\text { Ireland } \\
(n=54)\end{array}$ & $\begin{array}{l}\text { Scotland } \\
(n=61)\end{array}$ \\
\hline Current developments in teacher education & 4.74 & 4.51 & 4.45 \\
\hline Curriculum development & 4.22 & 4.02 & 4.23 \\
\hline Scholarly writing (e.g. articles, chapters, learning materials) & 4.13 & 3.76 & 3.92 \\
\hline Researching own practice & 4.10 & 3.96 & 4.00 \\
\hline Research skills & 3.96 & 3.76 & 3.89 \\
\hline Assessment & 3.95 & 4.17 & 4.05 \\
\hline $\begin{array}{l}\text { Integrating technology into own teaching and learning } \\
\text { strategies }\end{array}$ & 3.77 & 4.13 & 3.90 \\
\hline Subject knowledge and enhancement & 3.75 & 3.85 & 3.90 \\
\hline Presentation and participation at conferences & 3.66 & 3.17 & 3.18 \\
\hline Reviewing journal articles, conference abstracts etc. & 3.66 & 3.15 & 3.34 \\
\hline Coaching and mentoring student teachers & 3.46 & 3.59 & 3.56 \\
\hline Specialisation in academic administration & 2.32 & 2.52 & 2.39 \\
\hline
\end{tabular}

Table 4: Influential factors determining teacher educators' engagement in professional learning

\begin{tabular}{|l|l|l|l|}
\hline & England & Ireland & Scotland \\
\hline $\begin{array}{l}\text { Extent to which the activity is associated } \\
\text { with teaching and learning }\end{array}$ & $\mathbf{4 . 7 8}$ & $\mathbf{4 . 7 5}$ & $\mathbf{4 . 7 7}$ \\
\hline Knowledge of who the providers are & $\mathbf{4 . 7 4}$ & $\mathbf{5 . 0 2}$ & $\mathbf{5 . 0 8}$ \\
\hline Availability of staff cover & $\mathbf{4 . 5 1}$ & $\mathbf{4 . 8 9}$ & $\mathbf{4 . 6 0}$ \\
\hline $\begin{array}{l}\text { Extent to which a salary rise might be one } \\
\text { outcome of the professional learning } \\
\text { activity }\end{array}$ & 2.51 & 2.72 & 2.39 \\
\hline Location of activity & 4.40 & 4.65 & 4.32 \\
\hline $\begin{array}{l}\text { Extent to which activity addresses research } \\
\text { and writing skills }\end{array}$ & 4.09 & 4.41 & 4.16 \\
\hline Networking potential & 4.17 & 4.41 & 4.00 \\
\hline Cost of the activity & 4.49 & 4.28 & 4.21 \\
\hline
\end{tabular}

